AperTO - Archivio Istituzionale Open Access dell'Università di Torino

\title{
Foster Care of Foreign Minors in Italy: An Intercultural or Neo-Assimilationist Practice?
}

\section{This is the author's manuscript}

Original Citation:

Availability:

This version is available http://hdl.handle.net/2318/1561069

since 2016-07-05T17:08:51Z

Published version:

DOI:10.1093/lawfam/ebw005

Terms of use:

Open Access

Anyone can freely access the full text of works made available as "Open Access". Works made available under a Creative Commons license can be used according to the terms and conditions of said license. Use of all other works requires consent of the right holder (author or publisher) if not exempted from copyright protection by the applicable law. 
This is the post print version of the article published in Int $\mathrm{J}$ Law Policy Family (2016) 30 (2): 179-196 doi:10.1093/lawfam/ebw005

\section{Foster care of foreign minors in Italy: an intercultural or neo-assimilationist practice?}

by Joëlle Long, Law Department, University of Turin, Italy and Roberta Ricucci, Department of Culture, Politics and Society, University of Turin, Italy.

\section{Abstract}

This article aims to investigate how the foster care of foreign children is perceived and managed in a relatively recent immigration country such as Italy. Combining legal and sociological perspectives and methodology, we shall discuss whether and how foster care can effectively support immigrants' parenting and how interethnic fostering can avoid being transformed into a neo-assimilationist practice. Through analysis of domestic case law and qualitative interviews with social and legal practitioners, representatives of the administration and of migrants' associations, we shall identify national and local foster-care practices. Specific attention will be devoted to the role of the 'cultural variable' in the decision to remove offspring from their birth parents and place them in care, and to the conservation of the foster-children's cultural, religious and linguistic heritage. As a case study of problems and perspectives, we shall focus on Turin, one of the Italian cities most committed to the reception and integration of immigrants, focussing especially on the protection of minors.

\section{Introduction}

\footnotetext{
- The introduction and conclusion sections were written jointly; Section 3 by J. Long and sections 2 and 4 by R. Ricucci.
} 
Immigrant children in Italy fall into various categories. Besides minors belonging to the second generation (those born in Italy) there are those who have been reunited with their parents, as well as those who have arrived in Italy on their own, so-called unaccompanied foreign minors (see Ricucci, 2014). The latter category includes minors arriving in Italy (for instance from Afghanistan, Somalia, Ghana and Mali) requesting international protection and asylum. This element distinguishes Italy from other European countries, where minors fleeing from war are mostly accompanied by their parents (European Migration Network 2015; Eurostat 2015).

All of them are in some way immigrant children, but they have diverse features requiring different means to help them achieve solid growth, and different interventions and services to respond to their needs (Billari and Dalla Zuanna, 2008). Whilst concern for the immigrant minor requires the ability to adopt a differentiated approach, this is also necessary for immigrant parents, who have to perform the parental role in a context different from the one in which they grew up, and who have developed their own norms, values and caring strategies (Rumbaut, 1994).

As the experiences of migration in Germany and the United States have already shown, the relationship between the host society (and its services) and immigrant families (and their educational styles) may be fraught with misunderstandings and cultural incidents. Parenting practices are also culturally situated practices, so that without intercultural training they may be misinterpreted. In their new life-contexts, foreign families therefore have to justify behaviour that is customary in their countries of origin (Portes and Rumbaut, 2001; Crul, Schneider and Leslie, 2012). Added to this is the fact that they often have to manage precarious and arduous integration pathways, the effects of which impact on relations within 
the parental couple and between them and their children (Ambrosini, Bonizzoni and Caneva, 2010). When the family situation is compromised and the child's welfare is at risk, welfare institutions must intervene. One possible solution is foster care, by which is meant temporary removal of a child from the nuclear family and his/her placement with another family. ${ }^{1}$

On the one hand, this arrangement provides protection to children temporarily deprived of a suitable family environment through their transitory inclusion in another family; on the other, it supports the fragile parenting skills which sometimes characterize immigrant families with scant social-occupational integration into Italian society and poor housing conditions (Saraceno, Sartor, Sciortino, 2013).

On the one hand, this arrangement provides protection to children temporarily deprived of a suitable family environment through their transitory inclusion in another family; on the other, it supports the fragile parenting skills which sometimes characterize immigrant families with scant social-occupational integration into Italian society and poor housing conditions (Saraceno, Sartor, Sciortino, 2013).

The aim of this article is to investigate how foster care is used and perceived and handled in a relatively recent immigration country such as Italy. ${ }^{2}$ It addresses the following questions. Amid growing demand for the protection of immigrant children, can foster care (originally devised and developed to respond to the problems of Italian families) be an effective solution? And, if so, under what conditions? Moreover, how can the risk that fostering may devalue the educational systems of the foreign child's family and culture of origin be avoided? How can it be ensured that foster care effectively supports immigrants' parenting? How can interethnic fostering avoid transforming foster children into children who are culturally Italian but because of citizenship laws based on ius sanguinis rather than ius soli or ius domiciliary will 
have great difficulty obtaining Italian citizenship (and the rights and stability deriving from it), notwithstanding the facts that they were born in Italy and have spent their whole lives in the country?

The article will try to answer these questions by using an interdisciplinary approach which combines legal and sociological methodology and perspectives. Section 2 presents the context and issues concerning foreign families. Section 3 then considers two problematic issues evidenced in judicial case law: the role of the 'cultural variable' in assessment of parental mistreatment of the child and the protection of the fostered child's cultural identity. In light of interviews conducted with public practitioners and representatives of ethnic and/or cultural associations, Section 4 will seek to define some good practices. Section 5 will present the conclusions.

\section{Foreign families with children: an increasingly important question}

Growing numbers of foreign minors live in Italy (Istat, 2014). Even in recent years, with a slowdown in immigrant arrivals for work purposes, family reunifications have continued to increase (Unar, 2014). It seems almost as if a process of normalization is in progress - as evidenced by numerous studies on foreign adolescents, which depict their 'identikit' thus: they live in families larger than those of their Italian counterparts; they feel close to the Italian way of life; they attend school with average results; less than half of them expect to continue their education by attending university; they do not have great hopes for the future, which for many of them may not even be in Italy (Barbagli and Schmoll, 2011). They have the same lifestyle as many of their Italian counterparts: cellphone, Internet, music, tendency to dress in the brand of the moment (Save the Children, 2015). 
Table 1. Italy. Foreign population: total, minors and second generation (2006-2013, as of 1 January)

\begin{tabular}{|c|c|c|c|c|c|}
\hline $\begin{array}{c}\text { Foreign } \\
\text { population }\end{array}$ & 2006 & 2007 & 2008 & 2010 & 2013 \\
\hline Residents & $2,670,5$ & $3,432,6$ & $3,891,2$ & $4,235,0$ & $4,387,7$ \\
14 & 51 & 93 & 59 & 21 \\
\hline Minors & 665,625 & 767,060 & 862,453 & 932,675 & 953,785 \\
\hline $\begin{array}{l}\text { Incidence } \\
\text { of minors on } \\
\text { foreign } \\
\text { population } \\
(\%)\end{array}$ & 22.6 & 22.3 & 22.2 & 22.0 & 21.7 \\
\hline
\end{tabular}

Source: Istat 2014.

Children and adolescents who have entered Italy for family reunification today constitute the vexed question addressed by scholars, on the one hand, and practitioners on the other (Bianchi, 2011). As said, they form a highly heterogeneous group which the literature labours to define. In fact, whilst the migration that they have personally experienced or heard recounted is sometimes a marker too heavy to be ignored, these young people are more than foreigners. They are above all adolescents and youths in their school years who must undertake the 'double transition' to both adulthood and the host society (Pocaterra, Colloca, Gulli, 2009; Conti, 2012), processes that come about in family contexts sometimes already sorely tried by the migration process.

In fact, the obstacles encountered by immigrant families concern not only difficult reunion after years of separation but also re-interpretation of parental roles in social settings different from those to which the parents are accustomed. They also experience a sense of isolation, so that they seek out co-nationals for comfort and advice on how to live in and interact with the host society. 
The difficulties of reunification are increased by the (unwritten) law of migration whereby immigrants must present themselves to relatives and co-nationals in the country of origin as having succeeded in their enterprise. They must conceal the difficulties encountered, their uncertain legal status, precarious employment, and poor housing conditions (Ambrosini and Abbatecola, 2010). These rules apply to spouses and parents in Italy who send money, gifts, and stories of a non-existent prosperity to their relatives in the home country. The moment of reunification reveals the truth of the parents' living and working conditions.

Reunification may disrupt the stability of the family unit due to the discrepancy between the world imagined and the world encountered, between the success described (or hoped for) by the migrant and the actual reality in which s/he lives. Hence, contact with the new reality by the reunited children - already beset with problems of settling into a new context - is likely to be complicated by their discovery that the parents have been socially downgraded (Balsamo, 2003). The reactions may be disruptive and undermine the fragile (and imagined) rebalance brought about by the family's (parents and children) reunification (Besozzi, Colombo and Santagati, 2012).

Performance of the parental role suffers setbacks at the emotional level: the reunited children no longer recognize the parental authority of adults whom they feel have 'abandoned' and 'deceived' them. As a cultural mediator interviewed during the research put it:

"The children often come to Italy unwillingly. They must leave friends, grandparents, and familiar places for a new life. They often deal with the journey by imagining a life of ease, which they will not find in Italy. The impact with the reality is painful. The parents have unskilled jobs, the mothers are carers and rarely at home. And the home is not what they had 
imagined. Conflicts arise, and require the intervention of social services." (Civil servant, Municipal Office for Foreign Minors)

As regards active support - i.e. the capacity to assist the children in their studies and as they mature in Italy - reunification may put the family under severe strain, at times requiring intervention by the social services (Donati, 2014). Although mothers are the central figures in the socialization of children, their heavy workloads, as well as the inherent fragility of integration, often increase conflict within the family.

Also families formed in Italy by immigrants ${ }^{3}$ may experience difficulties. The absence of a supporting kinship network and socio-economic precariousness are factors that may undermine the stability of the family and hamper the child's growth and development so that it is necessary for social services to intervene.

Finally to be considered are 'unaccompanied foreign minors' (or 'separated minors' as they are termed in other European countries). There are three characteristics that distinguish this group: a) citizenship of a non-EU country; b) minority age; c) the absence of a responsible adult. There are two main factors that attract these children to Italy. The first is that arrival in Italy under the age of eighteen entitles them to rights because of their young age, but also exposes them to the risk of becoming victims (more or less conscious) of exploitation. The second factor is the central importance of the relationship with the area where they arrive, a place or a 'street family' on which they sometimes rely (Giovannetti, 2014). And it is the territory, as the locus in which the tangled skein of integration unravels, that must be considered in order to understand how unaccompanied foreign children 'accomplish' their migration projects, who the actors involved are, and through what trajectories those minors are recognized and accompanied to adulthood and, eventually, citizenship. The consideration is necessarily partial, because the local institutions fail to identify the 'invisible' unaccompanied foreign minors, those who construct their pathways to integration in the shadows, where they evade controls and are often beguiled by chances to make easy money 
even at the cost of violence and exploitation. For those who instead become (voluntarily) visible or are intercepted by the police or social workers, foster care may be a solution.

In the category of unaccompanied minors are included minors who arrive in Italy requesting asylum. The majority (more than 90\%) of such arrivals requesting asylum are men alone (Anci et al. 2015). With regard to minors, classified as unaccompanied minors, most (65\%) are young people in the 16-17 age-group. Therefore there seems to have been a lowering of the average age since 2013, considering that some of them (1\%) are between 11 and 13 years old, and there is an increase (17\%) in the number of 14-15-year-olds. These minors are placed in welcoming structures as part of an ad hoc welcoming strategy directed at unaccompanied foreign minors requesting asylum, where they are inserted in educational and training paths and given psychological assistance.

\section{Some problematic issues}

\subsection{An acid test}

Analysis of foster care in migratory contexts highlights problematic issues that, at least in part, transcend the fostering system and the phenomenon of migration to perform a mirroring function that brings out - through the relationship between foreigners and the host society criticalities in the interaction between institutions and citizens (Sayad, 2001). Firstly, the difficulty of assessing educational models 'other' than those of the practitioners evaluating parental competencies also arises with reference to families of Italian citizens belonging to ethnic, religious, or cultural minorities: the numerically most significant example is that of Roma families, around half of which have Italian citizenship. ${ }^{4}$ Secondly, as is obvious, the question of how to assess the parenting skills of immigrant parents arises not only in foster care but also in adoption, since both involve the removal of the child from the parents as a consequence of their inability to take care of their offspring. Thirdly, the need for foster care 
to be accompanied by an efficacious plan to support 'fragile' parenthood obviously concerns native families as well.

Examination of the critical issues that arise in immigrant foster care is of especial interest because they are amplified. Foster care is more complex and economically costly than adoption. It usually requires multiple interventions: to restore the parenting skills of the parents, as well as to support the child and the foster family. Moreover, as already said, migrant parenting is vulnerable because of the frequent occurrence of factors such as a lack of support networks, isolation, and poverty. This, together with the fact that foreign households often access social services when the family situation has deteriorated considerably, entails that foreign minors are over-represented in the statistics on children placed in foster care. ${ }^{5}$

This finding is confirmed by the case-law of the European Court of Human Rights: half of the condemnations of Italy in regard to parenting assessment and support in the period 19992015 have concerned migrant families. In the cases Todorova v. Italy (ECHR, 13 January 2009, application n. 33932/06) and Zhou v. Italy (ECHR, 21 January 2014, application n. 33773/11), the applicants were immigrant women, respectively of Bulgarian and Chinese nationality, who had had children in their countries of origin and then fallen pregnant in Italy, where they had no kinship or friendship networks. In Akinnibosun v. Italy (ECHR, 16 July 2015, application n. 9056/14), a Nigerian father who had arrived in Italy from Libya on a boat with his under-age daughter had been unjustly detained for three years, during which the relationship with the girl had been interrupted, with predictable difficulties of restoring it after his release from prison. In E. P. v. Italy (ECHR, 16 November 1999, application n. 31127/96), the applicant was an Italian woman who had returned to Italy after a long period of migration to Greece, and in her home country had encountered the difficulties commonly faced by immigrants (lack of support networks, material hardships, etc.). The European Court has 
censured Italy on the following grounds: inadequate information given to immigrant parents of their rights and how to assert them (E.P., Todorova); the inadequacy of measures to support fragile parenthood (E.P., Todorova, Akinnibosun); and the unjustified interruption or substantial impediment of contacts between children in foster care and birth parents $(E . P$., Akinnibosun).

\subsection{The role of the 'cultural variable' in the assessment of parental conduct and the protection of the cultural identity of the child in foster care}

In this section, we selectively focus on two problematic issues evidenced by case law $^{6}$ and interviews with legal and social practitioners: the role of the 'cultural variable' in assessment of parental mistreatment of the child (Elliott and Urquiza, 2006; Caso and Beretta, 2010; Confente, 2012; Morozzo della Rocca, 2012); protection of the fostered child's cultural identity (Anderson, 2014).

According to Italian law, foster care provides a safe family environment for children whose birth parents are unable to care for them $)^{7}$. The parental unsuitability must be transitory: that is, it must be remediable within a period of time considered appropriate in relation to the child's age and resilience. If the damage to the offspring is irreparable, or if the recovery time is deemed excessively long, recourse is made, not to foster care, but to termination of parental rights and then adoption.

In the case of immigrants, assessment of the existence of parental conduct damaging to the child is particularly complex because defining the boundary between 'different normal education' and parental 'unsuitability' (and thus between normal and pathological) requires prior 'culture-free' identification of a minimum level of care: that is, the core values that 
should characterize the relationship between parent and child. These values, however, are elusive because they change over time and are influenced by the cultural and social stereotypes of the practitioner conducting the assessment.

Examination of the relative case law makes it possible to identify the 'misdiagnoses' ${ }^{8}$ (or 'cultural misunderstandings, ${ }^{9}$ ) most frequent in cross-cultural situations: that is, the culturally-conditioned parenting behaviours most commonly misinterpreted by practitioners engaged in the assessment of parenting skills. They concern inflexible interpretation of the delegation of parental tasks to third parties as an unacceptable relinquishment of parental responsibilities; outright condemnation of a parent who has made an under-age child work or beg; the use of caregiving practices alien to the culture of the host country (e.g. weaning a baby with spicy rice, having him/her drink his/her own urine for therapeutic purposes). ${ }^{10}$ These are accompanied by several sensational criminal cases, for instance the misinterpretation as sexual assaults of acts commonly performed by fathers in the culture of origin as expressions of affection and play. ${ }^{11}$

Furthermore, there is a striking tendency to medicalize in terms of mental illness parents' expressions of maladjustment due to the experience of immigration. ${ }^{12}$ In the E.P. v. Italy case, for instance, the diagnosis of the mother's psychosis was made on the basis of information provided to the doctor by the sister-in-law of the woman, who had never had contact with her before her arrival in Italy. In a Turin case, a child was urgently placed in a foster home following compulsory medical treatment undergone by the Nigerian immigrant mother ${ }^{13}$. When fire-fighters and police had broken into her apartment because of her refusal to open the door so that they could check a water leak reported by neighbours, she had retreated with the baby in her arms to the window, a gesture interpreted without further investigations as an attempt at self-harm. 
The above-mentioned 'misdiagnoses' appear to result from two opposing conceptual approaches: one may be called 'assimilationist' ${ }^{14}$, the other 'justificationist' ${ }^{15}$.

According to the assimilationist model, the social and cultural background of the immigrant is essentially irrelevant. The principles of equality and secularity of the state require immigrants to conform to the cultural models predominant in the host country. Noncompliance with these models is assumed to be deviance, and therefore indicative of pathology in the relationship between parent and child. For instance, the Court of Appeal of Naples, in the case of Ghanaian parents who entrusted at birth their child to an Italian couple and then changed their minds after some years and asked for their daughter's return, ruled that foster care should be maintained because it could not be considered an exemption to the voluntary relinquishment of parental rights and responsibilities "... that they were conditioned in management of their parental responsibility by their culture and its peculiar traditions. The primary and fundamental right of the child to full and integral development ... cannot be disregarded in homage to the parent's right to a particular lifestyle such to jeopardize it." 16 The same line of reasoning was taken by the Court of Appeal of Rome when it declared the adoptability of a Kenyan boy relying on a comparative examination of the current situation of the child, placed in foster care with an Italian couple, and the social and cultural condition of the birth mother, a single woman isolated from the social context of the host country and with "emotional inadequacy towards her son". ${ }^{17}$ In both these cases courts firmly condemn parental behaviours which could be explained (and may be justified) with the parents' cultural background, without delving deeply into the effects of such actions on the child.

The risk of an assimilationist approach is also evident during the child's placement outside the family. In fact, conservation of the fostered child's cultural, religious and linguistic heritage in interethnic fostering should be functional to the child's reintegration into the 
family of origin, which - at least in the intent of the legislator - should be the outcome of the fostering arrangement. Sometimes foster families instead seek to inculcate the child with their way of life and their religion. ${ }^{18}$ For their part, the practitioners appointed to assess and support the family of origin's fragile parenting skills sometimes tend to impose ('teach') child-raising methods alien to the family's culture of origin (e.g. weaning should begin with the administration of pureed fruit and then vegetable broth). Furthermore, they usually prohibit the parents from using the mother tongue during supervised visitation of the child, on the grounds that the visit supervisor or facilitator is unable to follow the conversation in that language would prevent him/her from adequately assist and protect the child against potential prejudices arising from the parents' behaviour.

By contrast, the 'justificationist' approach gives importance to the cultural variable, although in practice this may result in discrimination between the levels of protection afforded to native and foreign minors.

Sometimes, for example, courts cite the family's 'lifestyle' to exclude the perception (and therefore the existence) of damage to the child due to the parents' behaviour. Instances of this kind now occur with some frequency in proceedings relative to Roma families (either Italian or foreign). For instance, a 1992 judgement by the juvenile court of Venice stated that "the developmental damage should be related, not to abstract criteria, but to the objective reality into which baby M. was born, a community of Roma travellers who are unaware of ways of life other than their own, and change to which would suppress their ethnic identity. Travellers cannot be induced to adopt a set of behaviours related to our ordinary criteria without doing violence to ways of life natural to them". ${ }^{19}$ Based on the same logic are considerations contained in two rulings by the Juvenile Court of Naples with reference to cases of Ghanaian minors entrusted by their parents at birth, and for a long time thereafter, to Italian foster 
carers. The reports by social services mentioned in the judgements stated that the decision by the parents to play a marginal role in their daughter's life, despite having opportunities to establish an intense emotional relationship with her (the mother had been hired as a family helper by the fosterers), derived from the "common denominator of almost all couples of colour with offspring, who, on assuring themselves of the well-being of their children, do not consider it necessary to follow them as they grow up" because "their customs, so very different from ours, allow growth to be delegated to others while maintaining parental custody". ${ }^{20}$ The court also included among the decisive factors in favour of the child's return to her family the fact that only contact with people of her ethnic community could ensure her harmonious development and therefore her best interests. ${ }^{21}$

As shown by the relevant literature and case law, both the justificationist and assimilationist models are to be rejected in favour of an 'intercultural' approach. The importance of the child's cultural background cannot be determined a priori; rather, it must be assessed case by case in light of the circumstances.

With reference, for example, to the delegation of parental responsibilities to a third party, it is necessary to determine whether such delegation is complete and for a period of time sufficient for consolidation of a de facto parental relationship between the child and the foster carers, with marginalization of the role of the birth parents. In this case, the latter cannot demand the child's return to the family: “... what should be considered is the actual truth for the minor and, in particular, the possible existence of abandonment by the parents". ${ }^{22}$ If instead the delegation is for a short period of time (as in the Zhou v. Italy case) and no evidence exists of the unsuitability of the foster carers, there is no reason to conclude that harm has been caused to the child. 
Similar considerations apply to the involvement of children in work or begging. It must be determined whether there exists a valid and proven affective relationship, ${ }^{23}$ whether the child attends school regularly, ${ }^{24}$ and whether the minor has an active or passive role in the begging. An intercultural approach also requires particular attention to be paid to the information given to the birth parents and the foster family. The parents must be able to understand what is happening and to assert their rights before the authorities called upon to decide and manage the foster care, since protection of the right of parents to respect for family life is functional to respect of the child's right to grow up in his/her family. ${ }^{25}$ Interesting in this regard are projects by the diplomatic missions of some countries, especially Latin American, to support their nationals subject to proceedings by the juvenile courts. Particularly active in Italy is Ecuador, which has devised a specific programme of psychological, social and legal assistance under the slogan Mamma es mama. Tu país te respalda (Mum is mum. Your country supports you). ${ }^{26}$

Moreover, social services and foster families should be made aware of the importance for the fostered minor of preserving his/her ties with cultural, religious and linguistic traditions. To this end, maintaining contact between the child and the family of origin during the placement outside the home - maintenance required by the law but, as said, not infrequently neglected - is of crucial importance. Homocultural fostering in families or with individuals of the same ethnicity as the child can be a valuable resource and is now spreading in Italy thanks to the collaboration of ethnic associations (see section 4). However, it is not always the best choice: the parents themselves sometimes expressly ask for the child to be fostered by Italian citizens, in order to promote his or her integration into Italian society and to keep the community of origin unaware of their difficulties.

\section{Constructing a foster care culture in an intercultural framework}


Attention to different cultural practices of childcare and performance of the parental role characterizes the work of not only judges but also social-welfare practitioners and, more generally, persons involved in the education of children (teachers, social workers involved in after-school activity, street educators, sports coaches). The other side of the work of the courts is undertaken by the offices responsible for the management of foster placements and promotion of a fostering culture among families. This is a task which is both complex and delicate, and in which work against prejudices and stereotypes is accompanied by education. Open-mindedness, however, is not enough for a good 'foster care project', especially in the case of foreign minors fostered by Italian couples and foreign minors by immigrant families.

"It's hard to think that a family would want to open their home to teenagers that the newspapers depict as drug pushers. We also have difficulties with the families of the same origin as the children. The crisis has wiped out what little there was of community solidarity. No wonder. Many families have broken up, with the fathers going to work in other regions or the mothers returning to Morocco. How can you ask them to look after a child or a teenager? You can't. It wouldn't be right for the children or for the families [...] Even with Italian families it's more difficult now than it was a few years ago. Dealing with foreign minors today is more difficult than in the past, there are more problematic cases. There are now also cases concerning the second generation, those who reject their parents because they feel Italian” (head of the Foreign Minors Office, City of Turin).

"We at the association have had good experiences of foreign children fostered by Italian families and some foreign families. But it's not easy. There's a lot of work to do in educating 
the adults before a foster placement can be considered. If I think about the families who have Afghan minors, I can only admire them. It isn't easy to handle adolescents who have adult experiences behind them and perceive themselves as adults. Many of them arrived on their own in Italy after a journey of over a year. Then they found themselves in a family, being treated as adolescents unable to look after themselves. It's easy to talk about foster care. We hear more and more about it in meetings with social services, but what we believe is lacking is preparation, ongoing discussion, psychological support. It's not just a question of funding" (ASAI Association representative).

These two interview extracts introduce some of the difficulties that confront the foster care of foreign minors today in Italy. These are issues that sometimes transcend the origin of the families (Italian or foreign); on other occasions, they concern homocultural fostering in the immigrant community.

The first difficulty (i.e. the relationship between native and immigrant families) consists in the need to inform, train, and update the array of practitioners (social workers, mediators, educators) with which adults and children come into contact in terms of the provenance of minors, the socio-cultural context, and educational practices in the case of unaccompanied or lone minors (Esposito and Vezzadini 2013).

This difficulty also concerns the second generation. As various studies have shown (Ricucci 2014), removals of children born in Italy from foreign parents are slowly increasing. Intervention in this case requires educational skills and approaches other than those employed in the education of minors born and partly socialised abroad, or children who have undergone precocious adultisation - as in the case of those who arrived in Italy unaccompanied by parents or adult reference figures. 
Another common concern is the need to flank childcare and educational activities with psychological and/or ethno-psychological support (Castiglioni, Riva, Inghilleri 2010). In regard to both children and pre-adolescents and adolescents belonging to families whose cultural references are different from those of the context (school, peers, recreationalexpressive activities) in which those minors are growing up, analysis is required on how to revise, redirect, and redefine educational methods and values liable to reify themselves in the eyes of these adults too closely involved in the relationship with the child to be able to assume a detached view on their activities. The spread of cross-cultural psychology practices in support of childcare practitioners and foster families that have to mediate among different, or even contrasting, contexts, norms, traditions and values is necessary (Berry 1997; Bhatia and Ram 2009).

As regards homocultural foster placements, first to be borne in mind are the difficulties of the current period. Whilst on the one hand the effects of the economic crisis have made it less possible for foreign families to make themselves available for homocultural fostering, on the other hand the funds provided for those families who will be available for welcoming a child can be considered an incentive for their availability. Such willingness to foster should be evaluated carefully to prevent exploitation of foster care, given that it accompanies the children's growth and mental and physical development. The delicate nature of such intervention has been the topic of a large body of literature (Fornari, Scivoletto 2007; Ferrari 2010): in every educational action, besides the facilities and financial resources available to organize activities, the most significant role is played by people, especially those interacting with the children, who assist them in defining their biographies as adolescents or maturing young people (in the case of unaccompanied minors) already with adult experiences which they have not had time to metabolize or to understand fully. 
A further difficulty concerns the understanding of foster care by the foreign families themselves - not only those subject to a child removal order but also, and especially, those involved in caring for co-national minors. Whilst the emphasis above was on the practitioners, now at the centre of attention are foreign men and women or those already naturalized as Italian but with a foreign migratory background. Foster care is a practice still unclear to many Italian families with low cultural capital. For families originating from other cultural contexts in which foster care is not present or is managed differently, ${ }^{27}$ the expressions 'take into foster care' or 'place in foster care' may generate cross-cultural misunderstandings or outright 'intercultural incidents' (Cohen Emerique 2011; Invernizzi and Williams 2008; Reggio and Santerini 2014). Such understanding becomes all the more necessary amid the increase in the number of children without Italian citizenship and given the positive educational outcomes of homocultural fostering. Insertion into a socio-cultural context in which norms, values, and language are shared may reduce the strangeness of the experience. Entering a new family and encountering new authority relations is a complex process for any child. If a foster child can rely on a common language, and on shared and interiorized everyday practices, an educative intervention as delicate as fostering may have an extra chance of success. This is even more so in a social context external to the family that is difficult for foreign citizens (minors or adults) in a state of fragility and social vulnerability: recent surveys on the attitudes of the Italian population to immigrants have shown increased resentment against them, accusing them of absorbing the already scant welfare resources available to natives (Eurobarometer 2014).

What measures can address these difficulties, which contribute to making foster care not only difficult to understand but also detrimental to the rights and autonomy of parents? What 
can be done to involve the growing number of well-established foreign families whose socioeconomic profile reflects that of the Italian middle class (Allasino and Eve 2008)?

Turin is one of the Italian cities most committed to the reception and integration of foreign citizens, and with particular regard to the protection of minors. Since the 1990s it has introduced numerous practices which form what can be called the 'Turin model'. The pillars of this model can be described as commitment, interconnection, and innovativeness. The projects and services dedicated to immigrant families and minors well evidence how these three factors combine in constructing reception and integration pathways; but they are also apparent in the actions of social workers, officials at employment centres, and school guidance counsellors, to become a modus operandi that gives the city a multiform reception network for real integration. We use the experience of the Casa dell'Affidamento to show how this model takes concrete form in the case of foster care.

Firstly, the commitment is apparent in the willingness of the service's workers to organize awareness-raising activities in immigrant communities, aimed at explaining how the society where they live is changing according to, e.g., new immigrant arrivals and the second generation's maturation. Thus a network of private social actors (from associations to ethnic chaplaincies or mosques), which disseminate information about foster care and its usefulness among the various communities, has been created.

Secondly, innovativeness. The involvement of cultural mediators and the development of communication actions in agreement with the immigrant communities has made it possible to assist families in trouble and to overcome fears and suspicions due to situations of vulnerability and fragility within the community. This is a practice with a policy learning perspective imported from Germany. The city of Turin has for some time experimented with the scheme through its inclusion in international networks such as Quartiers en Crise or CLIP 
- Cities for Local Integration Policies. Finally, the relationship between the institutional and non-institutional spheres gives rise to the third pillar of the 'Turin model': interconnection. The public/private alliance has proved successful in overcoming the mistrust and resistance of the families involved, as well as increasing the number of people available for 'day fostering', as an opportunity to experience and understand the meaning of entrusting minors to other adults and/or families.

How do foreign families respond to all these efforts? The interviews conducted with social services practitioners and representatives of ethnic associations raised two important issues. The first concerned the need not to consider - like other aspects of the relationship between immigrant families and the host society - all foreign communities as a monolithic whole. The second was part of a bigger picture and concerned the philosophy of integration from which ensues the decision to promote heterocultural or homocultural foster care (Zincone, Penninx and Borkert 2011). The social workers and associations argued that the decision should be made 'case by case' within a general framework of promoting integration in the sense of developing bicultural belonging to the life-context (Berry 1994). ${ }^{28}$ Indicated as necessary for both types of family, Italian and foreign, were accompaniment schemes or projects intended to encourage the sharing of fostering experiences, ${ }^{29}$ so that foster care becomes part an educational community or an 'educative surround' (school, leisure, activities in foster care) able to enhance integration and inter-cultural participation (Ambrosini 2012).

\section{Conclusions}

The use of foster care in immigrant contexts constitutes an acid test of the potential and drawbacks of multiculturalism. The examination of Italian practices related to foster care 
conducted in the previous sections showed the risk that it may become a form of "neoassimilation' through the pathologization of child-raising and educational models 'other' than those of the practitioners, as well as the annulment of the linguistic and cultural characteristics of the child during the period of foster care.

However, the sociology of migration suggests a different approach: that of 'bicultural practice' in which all the actors involved - families, social services, judicial authorities, ethnic associations - develop inter-cultural attitudes based on dialogue and exchange. Essential for this purpose, as we have seen, are information and education: for immigrant families on the values considered fundamental to the legal order of the host country, and - pending judicial assessment of the exercise of parental responsibility - on the purpose and possible outcomes of the proceedings and procedural rights; for foreign foster carers (these latter, for example, should have already answered - positively - the two classic questions of the sociology of migration: what relationship should I have with Italian society? What relationship should I have with my community of origin?).

Appropriate information and education, in fact, prevent the risk of cultural misunderstandings (consider the above examples of delegation of parental responsibilities and involvement of a child in work or begging), and they encourage the development of biographical trajectories of integration - the prelude to citizenship - if supported by robust pathways of socio-occupational inclusion and favourable reception. According to the abovementioned scheme proposed by Berry (1997), public actors and ethnic and/or intercultural associations should cooperate in order to produce the conditions for the bicultural integration of the child (and family) into the immigration context in which the relationship with origins intertwines positively with the secondary socialisation carried out in Italian-speaking settings.

\section{References}


- Allasino, E. and Eve, M. (2008). 'Ceto medio negato? Fenomeni migratori e nuove questioni', in A. Bagnasco (ed), Ceto medio. Perché e come occuparsene, Bologna: Il Mulino, pp. 285-322.

- Ambrosini, M. and Abatecola, E. (2010). Famiglie in movimento. Separazioni, legami, ritrovamenti nelle famiglie migranti, Genova: Il Melangolo.

- Ambrosini, M. (2012). Sociologia delle migrazioni, Bologna: Il Mulino.

- Ambrosini, M., Bonizzoni, P. and Caneva, E. (2010). Ritrovarsi altrove. Famiglie ricongiunte e adolescenti d'origine immigrata. Rapporto 2009, Milano: Fondazione ISMU, Regione Lombardia, Osservatorio Regionale per l'integrazione e la multietnicità.

- Anci, Caritas Italiana, Cittalia, Fondazione Migrantes and SPRAR (2015). Rapporto sulla protezione internazionale in Italia 2015, Roma.

- Anderson, M. (2014). 'Protecting the rights of indigenous and multicultural children and preserving their cultures in fostering and adoption', Family Court Review $\mathbf{5 2}$ (1), 6-27.

- Balsamo, F. (2003). Famiglie di migranti, Roma: Carocci.

- Barbagli, M. and Schmoll, C. (eds) (2011). La generazione dopo, Stranieri in Italia, Bologna: Il Mulino.

- Berry, J. W., (1994). 'Acculturative stress', in W. J. Lonner and R. S. Malpass (eds) Psychology and Culture, Boston, Allyn and Bacon, pp. 211-215.

- Berry, J. W. (1997). 'Immigration, acculturation, and adaptation', Applied Psychology, $46(1), 5-34$.

- Besozzi, Elena, Colombo Maddalena and Santagati Maria Grazia (2009). Giovani stranieri, nuovi cittadini, Milano: Franco Angeli. 
- Bhatia, S. and Ram, A. (2009). 'Theorizing Identity in Transnational and Diaspora Cultures: a critical approach to acculturation', International Journal of Intercultural Relations, 33 (2), 140-149.

- Bianchi, G. E. (2011). 'Italiani o nuova Italia? Citizenship and Attitudes Towards the Second Generation in Contemporary Italy', Journal of Modern Italian Studies, 16 (3), 321-333.

- Billari, F. and Dalla Zuanna, G. (2008). La rivoluzione nella culla. Il declino che non c’è, Bologna: Il Mulino.

- Pocaterra, R., Colloca, C. and G. Gulli (eds), Insieme a Scuola. Classi multietniche e processi di integrazione a Milano, Milano: Bruno Mondadori.

- Caso, L. and Beretta, G. (2010). 'La valutazione delle competenze genitoriali negli stranieri immigrati, in MinoriGiustizia, n. 2, 85-93.

- Castiglioni, M., Riva, E. and Inghilleri, P. (eds) (2010). Dispositivi transculturali per la cura degli adolescenti. Un modello di intervento, Milano: Franco Angeli Editore.

- Cohen-Emerique, M. (2011). Pour une approche interculturelle en travail social Théories et Pratiques, Rennes: Presses de l'EHESP.

- Confente, A. (2012). 'Responsabilità genitoriale in contesti interculturali', in MinoriGiustizia, n. 2, 90-99.

- Conti, C., 2012, 'Cittadini e cittadinanze. Giovani italiani e stranieri a confronto', in M. Livi Bacci (ed), Per un'Italia che riparta dai giovani: analisi e politiche, Available at http://www.neodemos.it (accessed on 25 August 2015), pp. 39-54. 
- Crul, M., Schneider, J. and Lelie, F. (eds). 2012. The European second generation compared: does the integration context matter?, Amsterdam: Amsterdam University Press.

- Donati, P. (2014). 'Le famiglie italiane di fronte all'immigrazione: le sfide di una convivenza civile', in Cifs (ed), Le famiglie di fronte alle sfide dell'immigrazione, Trento, Edizioni Centro Studi Erickson, pp. 21-57.

- Earner, I. (2007). 'Immigrant Families and Public Child Welfare: Barriers to Services and Approaches for Change', 86 Child Welfare, 63-91.

- Elliott, K. and Urquiza, A. (2006). 'Ethnicity, Culture, and Child Maltreatment', 62 (4) Journal of Social Issues, 787-809.

- Esposito, M. and Vezzadini, S. (eds) (2013). La mediazione interculturale come intervento sociale, Milano, Franco Angeli.

- Eurobarometer (2014). Public Opinion in the European Union. First Results, Bruxelles: European Commission.

- European Migration Network (2015). Policies, Practices and Data on Unaccompanied Minors in the EU Member States and Norway. Bruxelles: European Commission.

- Eurostat (2015). Asylum Quartely Report. Bruxelles: Eurostat.

- Ferrari, M. (2010). La frontiera interna. Welfare locale e pratiche sociali, Academia University Press, Firenze.

- Fornari, M., Scivoletto, C. (2007). 'L'affidamento omoculturale nell'accoglienza dei minori stranieri non accompagnati', MinoriGiustizia, n. 3, 97-108.

- Giovannetti, M. (2014). I minori stranieri non accompagnati in Italia, Roma: ANCICittalia. 
- Hafford, C. (2010). 'Sibling caretaking in immigrant families: Understanding cultural practices to inform child welfare practice and evaluation', Evaluation and Program Planning 33 (3), 294-302.

- Invernizzi, A. and Williams, J. (2008). Children and Citizenship, New York: Sage.

- ISTAT (2014). Indicatori demografici, Roma: Istat.

- Miazzi, L. (2012). 'Modelli educativi genitoriali in contesti interculturali: la prospettiva giuridica', MinoriGiustizia, n. 2, 156-192.

- Ministero del Lavoro e delle Politiche Sociali, (2014). Affidamenti familiare e collocamenti in comunità al 31.12.2012, Quaderni della ricerca sociale, n. 31, Roma.

- Morozzo della Rocca, P. (2012). 'Minori e minoranze. Il problema delle differenze', in Trattato di diritto di famiglia diretto da Paolo Zatti, Milano: Giuffrè, pp. 559-571.

- OsservAzione (2013). La tutela dei diritti dei bambini rom nel sistema italiano di protezione dei minori, Napoli: Marotta e Cafiero.

- Portes, A. and Rumbaut, R. G. (2001). Legacies: The Story of the Immigrant Second Generation, Berkeley: University of California Press.

- Reggio, P. and Santerini, M. (2014). Le competenze interculturali nel lavoro educativo, Roma: Carocci.

- Radjack, R., Baubetb, T., El Hagec, W., Taiebb, O. and Moro, M. R. (2012). 'Peut-on objectiver et éviter les erreurs diagnostiques en situation transculturelle?', Annales Médico-psychologiques, revue psychiatrique, 170 (8), 591-595.

- Ricucci, R., 2014, Second Generations on the Move in Italy: Children of Immigrants Coming of Age, Lanham, Lexington Books. 
- Rumbaut, R. G. (1994). 'The Crucible within: Ethnic Identity, Self-Esteem, and Segmented Assimilation among Children of Immigrants', International Migration Review, 28 (4), 748-794.

- Saletti Salza, C. (2010). Dalla tutela al genocidio?, Roma: CISU.

- Saletti Salza, C. (2014). Famiglie amputate. Le adozioni dei minori dal punto di vista dei rom, Roma: CISU.

- Saraceno C., Sartor F. and Sciortino G. (eds) (2013). Stranieri e diseguali, Bologna: Il Mulino.

- Save the Children (2015). Stili di vita dei bambini italiani, Roma: Save the Children.

- Stukes Chipungu, S. and Bent-Goodley, T. B. (2004). 'Meeting the Challenges of Contemporary Foster Care', Children, Families, and Foster Care, 14 (1), 74-93.

- Taliani, S. (2012). 'I prodotti dell'Italia: figli nigeriani tra tutela, diritto e amore materno (molesto?)', in MinoriGiustizia, n. 2, 39-53.

- Taliani, S. (2014). 'Il perito, il giudice e la bambina che non morirà', in MinoriGiustizia, n. 2, 158-164.

- UNAR (2014). Dossier Statistico Immigrazione, Roma: Ed. Idos.

- Zincone, G., Penninx, R. and Borkert, M. (eds) (2011). The policymaking of immigration and immigrants' integration in Europe, Amsterdam: AUP, Imiscoe Series.

\footnotetext{
${ }^{1}$ This is the notion of foster care as per Articles. 2-5 of Law 184 of 4 May 1983, which in Italy is the regulatory text on the matter. In most cases, the child's removal is decided by courts upon determining parental unsuitability. In a minority of cases, temporary 'respite care' is requested of the local social services by parents who realize they can not temporarily take care of their child, for example because they have no supporting kinship or friendship networks and need time to organize their household/work in a manner compatible with the
} 
needs of the minor, or because the child is severely disabled and the parents need a period of physical and emotional distance so that they can then resume care of the child. Excluded from this situation is placement in residential care facilities (which in Italy today account for 50\% of placements outside the family: sources: Ministero del Lavoro e delle Politiche Sociali, 2014: 10), and non-residential fostering (whereby the child spends only a few hours of the day with the foster carers).

${ }^{2}$ This paper pertains to the three-year interdisciplinary research project at the University of Turin entitled "Practices and Policies around Parenthood. Work-family balance and childcare in multicultural contexts", funded by the Compagnia di San Paolo and co-ordinated by Professor Manuela Naldini. As part of this project the authors have carried out in-depth quantitative and qualitative investigation of the fostering of foreign minors in the municipality of Turin. Used for the purposes of this article are the results of qualitative interviews: seven key informants (heads of the office of minors, the Casa dell'Affidamento, educational services of the City of Turin, and the F. Fanon, Pastorale Migranti, AMECE and ASAI associations).

${ }^{3}$ These are families formed in the host country by two immigrant spouses (from the same country of origin or two different ones).

${ }^{4}$ The antropologist Saletti Salza has long researched the adoption of Roma children in Italy, showing with quantitative and qualitative data that the cultural and social stereotype of Roma plays a significant role in the evaluation of the birth parents' competencies: see Saletti Salza, 2010 and 2014.

${ }^{5}$ The incidence of foreign minors in the total of fostered children is $17 \%$, and as high as $31 \%$ among children in care facilities (Ministero del Lavoro e delle Politiche Sociali, 2014: 1215). These high proportions are not exclusive to Italy, however: see Stukes Chipungu and Bent-Goodley, 2004.

${ }^{6}$ The survey was conducted on 24 judgements issued in the period 1992-2015 in regard to the foster care of foreign children and retrieved from the De Jure and Leggi d'Italia Professionale databases.

${ }^{7}$ Art.2 Law N. 184 of 4 May 1983 on Children's right to a family.

${ }^{8}$ The expression 'misdiagnosis' is used in cross-cultural psychiatry. See Radjack, Baubetb, El Hagec, Taiebb and Moro, 2012.

${ }^{9}$ Morozzo della Rocca, 2012: 559.

${ }^{10}$ Italian case law on the matter is recent. The first cases date back to the 1990s and mainly concern Roma children, many of them Italian citizens. The frequency of prejudices against the parenting skills of Roma and the lack of targeted actions to encourage the reintegration of Roma children are evidenced by the over-representation of Roma children in foster homes (OsservAzione, 2012: 19), as well by declarations of adoptability (Saletti Salza, 2010)

${ }^{11}$ See Tribunale di Reggio Emilia, 21 November 2012 which acquitted the parents of the crime. The case concerned an Albanian family whose father had been arrested and prosecuted for sexual assault on his son. The criminal offence report was conveyed to the prosecutor by the staff of the nursery attended by the boy. Audiovisual recordings authorized by the prosecutor in the parents' bedroom showed that the father would kiss the boy's genitals for a few seconds. However, examination of the child and the testimonies acquired showed that this was a traditional way in which Albanian fathers express paternal affection to their sons, without abusive connotations. The case had caused uproar in the Albanian community.

${ }^{12}$ This is well known in cross-cultural psychiatry and ethnopsychiatry.

${ }^{13}$ The case is recounted by Taliani, 2014: 159. 
${ }^{14}$ Morozzo della Rocca, 2012: 559, instead prefers to speak of a risk of 'denialism' when no importance is given to the cultural identity of persons.

15 The expression is from Morozzo della Rocca, 2012: 558.

${ }^{16}$ Thus Corte di Appello di Napoli, decree of 9 November 1995, in Il diritto di famiglia e delle persone, 1997, 587, which, despite the parents' application for her return, confirmed the foster care placement.

${ }^{17}$ The decision was criticised and overruled by Corte di Cassazione, 22 November 2013, n.26204. Migrants" "anti-social behaviours" towards the host country and "emotional inadequacy" compared to general standards are often underlined in foster care and adoption case law. See Corte di Appello di Salerno, 9 December 2009, in De Jure, 2015 confirming the foster care placement of a Romanian minor and emphasising the refusal by the parents to make any attempt to integrate into society and to find work. Likewise, Corte di Cassazione, 6 February 2013, n. 2780 endorsed the declaration of adoptability of the child of a trafficked Nigerian mother, considering as adequate the grounds cited by the lower courts: the woman's uncooperative behaviour; her tendency to alienate and isolate herself; and her refusal of psychotherapy for borderline personality disorder.

${ }^{18}$ In a social report on the just-mentioned case of the Ghanaian child entrusted by her parents at birth to an Italian couple, one reads "Elisabeth is a little girl who goes to Mass on Sundays, who ... speaks only Italian, who eats like an Italian..." (Corte di Appello di Napoli, decree of 9 November 1995). The same situation occurred in the case examined by Corte di Cassazione, 4 November, 1996, n. 9576, in Famiglia e diritto 1997, 25 (two Tunisian sisters in foster care had lost the ability to express themselves in their native language and had been "placed with a Catholic family which had them baptized") and in the case examined by the Corte di Appello di Napoli, 20 July, 2005, in Famiglia e diritto 2005, 905 (the foster carer of a Ghanaian baby girl said "I had her baptized and I also held a good party for her").

${ }^{19}$ Tribunale per $i$ minorenni di Venezia, 1 October 1993, in Il diritto di famiglia e delle persone, 1994, I, 251. The decree denied the existence of the state of abandonment of a Roma minor, whose mother had been arrested several times in acts of theft with the baby in her arms, stating that the social worker's report had declared that the child showed no signs of suffering and had normal development. Although this was probably an acceptable ruling, the statements in the text cannot be approved.

${ }^{20}$ Tribunale per $i$ minorenni di Napoli, decree 14 November 1994, in Il diritto di famiglia e delle persone, 1997, 613. The quotations are taken from the social service report (the ruling was subsequently amended by Corte di Appello di Napoli, 9 November 1995, cit.). Substantially similar in its conclusions is the report by the technical consultant to the Juvenile Court of Naples, which recounted the story of a little girl, also from Ghana, and also entrusted by her parents at birth and for six years to an Italian citizen: "Only by re-finding her origins and roots, which also represent the heritage of knowledge, values and affects of her family members, will A [the girl] feel protected ... and well integrated into a context respected by and respectful of the family community to which she belongs" (Corte di Appello di Napoli, 20 July 2005, in Il diritto di famiglia e delle persone, 2009, 90).

${ }^{21}$ Similarly, the already-mentioned ruling by the Tribunale per $i$ minorenni di Napoli in September 2003, subsequently amended on appeal by the Corte di Appello di Napoli, 20 July 2005 , cit., stated that "the child, by now old enough to realize that she is diverse [italics in original] ... but not from the family of origin, by virtue this diversity ... will quite easily be able to cope with the trauma of separation [from the foster carers]". 
${ }^{22}$ The Corte di Appello di Napoli 20 July 2005, in Il diritto di famiglia e delle persone 2005, p. 905 , confirmed the foster care placement of a Ghanaian girl entrusted from the first four months of life, and for six years, by the parents to a widowed Italian foster carer with adult children.

${ }^{23}$ The Tribunale per $i$ minorenni di Roma, 30 June 1992, in Il diritto di famiglia e delle persone, 1994, 635, declared the non-existence of the conditions for declaration of adoptability and termination of parental rights of two Bosnian Roma parents, considering their profound affective relationship with the child and their endeavour to fulfil her primary needs despite objective difficulties (the family was living "in a camp bereft of the minimum standards of hygiene ... services and facilities that could permit a decent standard of living"). Likewise, the Tribunale per i minorenni di Torino, 27 July 1999, in Diritto immigrazione e cittadinanza, 2000, n. 2, 147, ordered the return to her family of a Chinese girl exploited by her parents in their clothing workshop, following the girl's request to return to her family, and after inquiries showed that the mother had "managed to build a valid affective relationship with her, despite her unlawful employment in the worshop".

${ }^{24}$ These factors induced the court to exclude the existence of the crime of child neglect in the case of two sisters aged thirteen and seven found begging outside a supermarket in the absence of their parents: Tribunale di Rovigo, 4 May 2010, in Diritto immigrazione $e$ cittadinanza, 2010, n.3, 229.

${ }^{25}$ For an example see Tribunale per i minorenni di Roma, decree $30 \mathrm{June}$ 1992, in Il diritto di famiglia e delle persone, 1994, 639, which ordered the social services "to ensure fulfillment of the above provision [limitation of parental rights], and also to inform the parents about the content and purpose of the present decree".

${ }^{26}$ On 7 May 2015 a meeting was held at the consulate in Milan to describe the project and present its results. Specifically, the consulate provides financial assistance to Ecuadorian nationals, makes a cultural mediator available for family court hearings, and furnishes personalized legal, psychological and social work assistance. Moreover, it mounts awarenessraising campaigns targeted on both the Ecuadorian community and the local services. Finally, within the project, the Consul and his assistants have met the presidents of the juvenile courts, as well as mayors and municipal councillors for the family and social policies.

${ }^{27}$ An example is fostering through the kafalah system widespread in many Islamic countries. This does not involve a filial relationship between adopter and adoptee (similar to foster care); rather, it is characterized by an indefinite duration, entailing - if decided by the parents - full delegation of educational responsibility to the kafil until the fostered child comes of age.

${ }^{28}$ Berry's scheme proceeds from separation (maintenance of ethnic identity) to assimilation (identification with the majority group), thereby defining four specific attitudes towards acculturation. These are attitudes neither monolithic nor predetermined whose realization is conditioned by interacting elements, both at the micro/local level (e.g. the classroom context, the friendship group, etc.) and the macro/citizenship one (e.g. reception policies and integration strategies, etc.). One can speak of 'alternating biculturalism' (Phinney and DevicNavarro, 1997) when the subject alternates between the two identities in a manner functional to the time, place and role, in a sort of identity exploitation.

${ }^{29}$ The City of Turin, for example, from a policy transferability standpoint, has adopted a project devised by the City of Berlin intended to create a multicultural network of mothers so that they can share difficulties and problems of the fostering experience. 